
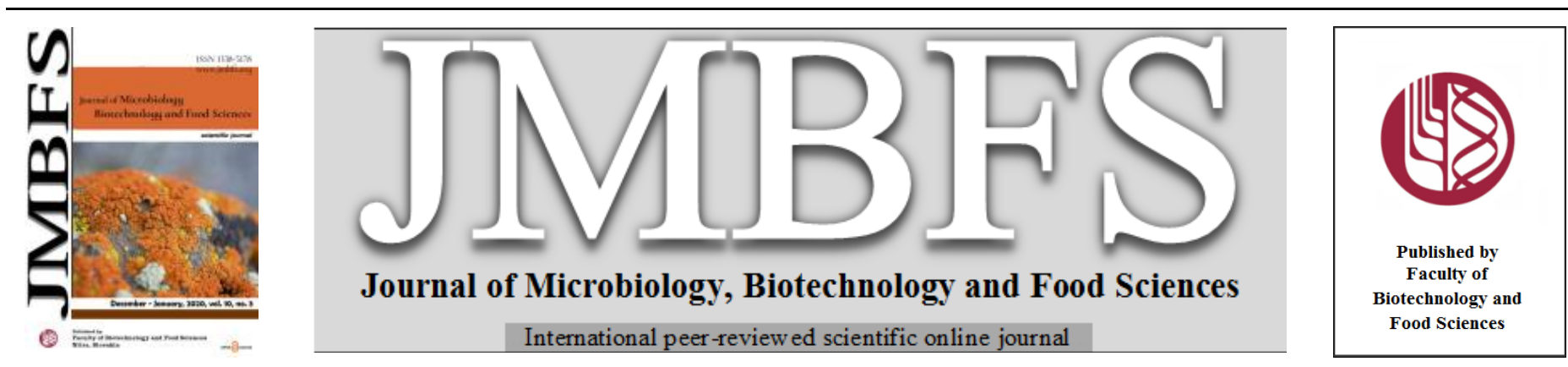

\title{
LACTOCOCCUS LACTIS STRAINS FROM INTESTINAL ORGAN OF BLACK TIPS SHARK CARCHARHINUS LIMBATUS PRODUCING NISIN-LIKE BACTERIOCIN ACTIVE AGAINST SHRIMP AND FISH PATHOGENS (VIBRIO PARAHAEMOLYTICUS AND VIBRIO ALGINOLYTICUS)
}

\section{Tengku Haziyamin Tengku Abdul Hamid*, Khairil Ikhwan Ahmad Zahli and Mohammed Alotaibi}

Address(es):

Department of Biotechnolohy, Kulliyyah of Science, International Islamic University Malaysia, Department of Biotechnology, Jalan Istana, 25200 Bandar Indera Mahkota, Kuantan, Malaysia.

*Corresponding author: haziyamin@iium.edu.my

doi: 10.15414/jmbfs.2020.10.3.354-360

ARTICLE INFO

Received 29. 4. 2020

Revised 6. 7. 2020

Accepted 8. 7. 2020

Published 1. 12. 2020

Regular article open $\mathcal{C A C C E S S}$

\begin{abstract}
Shark can be a potential source for host-associated probiotics destined to be used in aquaculture. In this study, intestinal tissues of Black tip shark (Carcharhinus limbatus) was used as the source sample for inhibition screening based on spot-on-lawn and agar well diffusion methods. Out of the 80 isolates, only four showed antagonistic activities against selected indicator strains. All of the 4 isolates FA1, FA2, FA3 and FA4 were found to be Gram positive coccus, non-spore former, oxidase and catalase negatives, as well as lactose fermenters. The isolate FA1, FA2, FA3 and FA4 were found to demonstrate broad range of inhibitory spectrum on gram-positive indicator bacterium (Staphylococcus aureus and Bacillus cereus) and the gram-negative bacterium (Escherichia coli, Pseudomonas aeruginosa, Salmonella typhimurium, Vibrio alginolyticus and Vibrio parahaemolyticus); with the highest inhibition zone at $20.0 \pm 0.1$ $\mathrm{mm}$, recorded on $V$. parahaemolyticus. The genotype of the isolates was characterized using $16 \mathrm{~S}$ rRNA sequencing. Each sequence with a given GenBank (NCBI) accession number (MN975529 for FA1; MN982712 for FA2; MN982711 for FA3; and MN982710 for FA4) showed at least $99 \%$ similarity with Lactococcus lactis subspecies. The crude cell free supernatant (CFS) of the isolates potentially contained a putative bacteriocin displaying nisin-like properties. The $\mathrm{pH}$ and catalase treatments showed that neither organic acid nor hydrogen peroxide $\left(\mathrm{H}_{2} \mathrm{O}_{2}\right)$ was the inhibitory component. An almost $95 \%$ inactivation of the CFS's antimicrobial activity was observed following treatment with trypsin suggested a presence of proteinaceous agent. Growth and inhibition studies on all isolated strains demonstrated that the inhibition properties were growth associated, with maximum inhibition achieved at $\sim 20.0 \pm 0.1 \mathrm{~mm}$ (or $\sim 168 \pm 17$ $\mathrm{AU} / \mathrm{ml}$ ) at 17 hours by FA2 strain against $V$. parahaemolyticus. A study on the mode of inhibition demonstrated a bactericidal killing against $V$. parahaemolyticus. The isolation of Lactococcus lactis strain from shark is rather unique since it was commonly reported to be isolated from human and animals. These strains show bacteriocinogenic properties, broad spectrum inhibition, and more importantly, they are able to antagonise some pathogens implicated in fish or shrimp diseases. Therefore, these strains have potential for use as probiotics in aquaculture.
\end{abstract}

Keywords: lactic acid bacteria, probiotic, nisin, Lactococcus lactis

\section{INTRODUCTION}

Probiotics are considered to play huge role in preventing many human and animal diseases. They are defined as 'live microorganisms that when administered in adequate amounts, they give health benefit to the host' (Gibson et al., 2017). Studies have shown that there are three main benefits that probiotics could provide to host cell; i.e., modulating host immune system, suppressing pathogenic organisms and releasing of microbial product such as bacteriocin that elicits necessary probiotic effect to the host organism (Oelschlaeger, 2010). Probiotic microorganisms are generally from Lactic acid bacteria (LAB) which includes gram positive bacterium from genera Lactobacillus, Leuconostoc, Lactococcus, Pediococcus and Bifidobacterium. Among these, Lactobacillus and Bifidobacterium are the prominent groups which have been commonly studied and used commercially (Heller, 2001). LAB are commonly known to produce various metabolites such as ethanol, formic acid, fatty acids, hydrogen peroxide, diacetyl, reuterin, reutericyclin and bacteriocins. Bacteriocin or bacteriocin-likesubstances (BLS) are ribosomally synthesized peptides or proteins produced by diverse groups of bacteria showing antibacterial properties. As these antimicrobial substances are natural, some of these were commercially developed as food preservatives (Zouhir et al., 2010).

Probiotics offer tremendous benefit not only to human but also to aquatic animals. Since the microbial community in the surrounding water actively exchanges with the microflora in fish, it plays a pivotal role in fish health and diseases. For instance in aquaculture, intensive or caged culture and adverse environmental condition are often attributed to the diseases (Banerjee, 2013).
Viral and bacterial diseases are considered to be the major limiting factor and constraint for the successful aquaculture production (Ninawe \& Selvin, 2009). Unfortunately, the excessive and routine use of chemical disinfectant in managing diseases, as well as the use of human antibiotic to promote animal growth have resulted in the emergence of resistant strains (Amenyogbe et al., 2020). Probiotics are considered as a beneficial alternative since they help reduce chemical and drug uses in aquaculture and will make fish products highly acceptable to consumers. Therefore, the search for a useful or suitable probiotic organisms have continuously been the focuses of many researchers during the last decade. Fish or other aquatic animal can be a potential source for probiotic organism. Realizing many benefits, the concept of host-associated probiotics has recently emerged (Lazado et al., 2015; Van Doan et al., 2020). Therefore, interest in probiotic organisms derived from fish or aquatic species are growing to be more attractive in aquacultures.

Internal tissues or organ in fishes harbour a significant population of microorganism especially of the fish intestine (Givens et al., 2015). However, fish microflora is substantially different from that of human or terrestrial animal. A high throughput pyrosequencing study on gut microbiome of 12 bony fishes and 3 shark species revealed that Proteobacteria dominated $(>50 \%)$ the fish gut with only a small remaining proportion was from Firmicutes (Givens et al., 2015). Therefore, $\gamma$-Proteobacteria such as Aeromonas sp., Escherichia coli, Photobacterium sp., Pseudomonas sp. and Vibrio sp. are the dominant genera whereas LAB can only be found in a small population in fishes. There has been very little research on gut microflora of marine fishes such as shark. Nevertheless, different members of microorganism were reported to have been 
isolated from shark. These include Lactobacilus pentosus isolated from grey carpet shark Chiloscyllium punctatum (Jiang et al., 2017); a non-LAB bacteria of Halomonadaceae family isolated from a dead shark (Zhen-Xing et al., 2016); Bacillus isolated from deep sea shark (Bindiya et al., 2015); and Pseudomonas putida isolated from shark skin (Ahmad et al., 2013).

The objectives of our study was to isolate and study the potential LAB strains from the intestine of a Black tip shark Carcharhinus limbatus, originated from Malaysian East Coast coastal water. Several Lactococcus lactis strains were isolated and the strains exhibited broad spectrum antagonism against both gram positive and gram negative indicator strains. These LABs are also potentia bacteriocin producers showing active inhibitory activities against some of the common fish pathogens, especially from Vibrio spp. The growth-inhibitory activities and the mode of inhibition against fish pathogens were evaluated. These properties will make these strains suitable host associated probiotics for use in aquaculture.

\section{MATERIAL AND METHODS}

\section{Shark and bacterial samples}

A shark sample of $1.3 \mathrm{~m}$ length, $40 \mathrm{~cm}$ diameter, approximately $10 \mathrm{~kg}$ was freshly purchased from early morning wet market near Kuantan (GPS 3.785756 , 103.316770). Later identification revealed that the fish belongs to Black tip shark or Carcharhinus limbatus. Based on International Union for Conservation of Nature (IUNC) red list, this shark species is classified under 'near threatened'. Despite of no extinction threat, our work on the fish carcass was officially documented and notified to the local fishery authority. The sample was promptly transported to the laboratory, dissected in sterile condition and the fish tissues $(\sim 200 \mathrm{~g}$ of intestines and spiral valve) were collected. The indicator bacterium used were Gram-positive Staphylococcus aureus and Bacillus cereus and the Gram-negative Escherichia coli, Pseudomonas aeruginosa, Salmonella typhimurium, Vibrio alginolyticus and Vibrio parahaemolyticus. All indicator strains were grown on Nutrient agar (NA) and Nutrient broth (NB) (Oxoid) at 30 ${ }^{\circ} \mathrm{C}$ for at least 20 hours. Most of the indicator strains used in this study were obtained from existing collection maintained by Kulliyyah of Science, International Islamic University Malaysia (Indera Mahkota Campus). A strain Vibrio alginolyticus was obtained from Department of Fisheries at Besut, Terengganu, Malaysia.

\section{LAB screening}

The fish tissues were homogenized in sterile saline and $0.1 \mathrm{~mL}$ of serially diluted samples $\left(10^{-2}\right.$ and $\left.10^{-3}\right)$ were spread onto deMan, Rogosa and Sharpe (MRS) agar followed by incubation at $30^{\circ} \mathrm{C}$ for $12-24$ hours. Single colonies formed were randomly selected and further sub-cultured on MRS agar. When needed, the selected colonies were cultivated in MRS broth for 12-18 hours and centrifuged at $10,000 \mathrm{x}$ g at $4^{\circ} \mathrm{C}$ for 15 minutes. The selected LAB strains showing inhibition were sub-cultured and preserved in $20 \mathrm{v} / \mathrm{v} \%$ glycerol at $-80^{\circ} \mathrm{C}$. The crude cell broth and cell free supernatant (CFS) were used in spot on lawn and agar well diffusion assays, respectively. In order to obtain CFS, broth was centrifuged to collect supernatant and filtrated $(0.22 \mu \mathrm{m}$, Millipore). For morphological and biochemical tests, the strains were subjected to standard gram staining protocols and further analysed by using light microscope (Nikon). Other biochemical tests; catalase, oxidase, motility and fermentation, were also carried out according to the standard protocols.

\section{Spot on lawn and Agar well diffusion assays}

Preliminary screening was done based on spot on lawn then followed by agar well diffusion methods as carried out by Lima et al. (2007). The indicator strain were grown up to $2 \times 10^{6} \mathrm{CFU} / \mathrm{mL}$ and spread on the NA (Oxoid) using sterilized cotton swab and allowed to dry. About $10 \mu \mathrm{L}$ cellular broth from LAB strains grown on MRS broth was pH adjusted (6.0) and spotted on the surface of the NA plates previously pre-seeded with indicator strains. The plates were incubated for at least $18 \mathrm{hr}$ at $30{ }^{\circ} \mathrm{C}$. For agar well diffusion assay, wells of $9 \mathrm{~mm}$ diameter were made using a cork borer on NA plate pre-spread with desired indicator strains. The well was filled with $100 \mu \mathrm{L}$ of the CFS from LAB previously grown on MRS broth. The plates were incubated for at least 18 hours at $30^{\circ} \mathrm{C}$ and the inhibition zone was measured. All antimicrobial tests were done in triplicate.

\section{Genotypic characterization}

The genomic extraction was carried out on the 4 LAB strains (Qiagen, 2016) and were used as the template for amplification of $16 \mathrm{~S}$ ribosomal using polymerase chain reaction (PCR). A pair of universal primers was used i.e., the forward (5'AGAGTTTGATCCTGGCTCAG-3') and the reverse (5'CCGTCAATTCCTTTGAGTTT-3') to amplify $1.5 \mathrm{~kb}$ fragment of $16 \mathrm{~S}$ rRNA gene (Edwards et al., 1989). The DNA template (5 $\mu$ l), each primers $(5.0 \mu \mathrm{l}, 10$ pmol) and $25.0 \mu 1$ of a 10x PCR master mix buffer (Fermentas, Lithuania) were mixed in a total reaction volume of $50 \mu \mathrm{l}$. The $10 \mathrm{x}$ PCR master mix at $\mathrm{pH} 8.3$ contained $50 \mathrm{mM}$ dNTP each (dATP, dCTP, dGTP and dTTP), $3 \mathrm{mM} \mathrm{MgCl}$, $100 \mathrm{mM} \mathrm{KCl}, 20 \mathrm{mM}$ Tris- $\mathrm{HCl}$, and $0.1 \mathrm{U \mu l}^{-1}$ Taq polymerase. The other parameters used in amplification cycle were similar as in our previous work (Yusuf \& Hamid., 2013). After amplification, the fragments were purified and further sequenced (First BASE Laboratories Sdn. Bhd., Malaysia). Sequence results generated were cleaned from noise and analysed for homology using an on-line BLASTN tool at National Center for Biotechnology Information, NCBI, accessible via http://www.ncbi.nlm.nih.gov. Several related strains selected from BLAST hit list were used to construct a phylogenetic tree. The tree was generated using an open source tool NGphylogey.fr available at https://ngphylogeny.fr/. In a single mode, the sequences were aligned (MAFFT), curated (BMGE), tree inferenced (FASTme) and rendered (Newick) (Lemoine et al., 2019). FastME step uses an improved version of Neighbour Joining (NJ) methods which performs topological moves by fast and sophisticated algorithms.

\section{Characterization of bacteriocin component in CFS}

In order to study effect of $\mathrm{pH}$ on inhibitory activities, $500 \mu \mathrm{l}$ CFS were adjusted to $\mathrm{pH} 4,5,6,8$ and 10 with either $\mathrm{HCl}$ or $\mathrm{NaOH}$, and incubated for 4 hours at room temperature and the inhibitions were measured by agar well diffusion. To investigate the effect of heat, CFS were incubated at $50,80,100$ and $121^{\circ} \mathrm{C}$ for 15 minutes (Hata et al., 2010). The treated CFS were then cooled to room temperature and their inhibitory effects were measured. Sensitivity of CFS components to various proteolytic enzymes (proteinase $\mathrm{K}$, trypsin, bromelain) and non-proteolytic enzymes (catalase and lysozyme) were evaluated in different enzyme reactions. Each enzyme reaction contained $200 \mu \mathrm{l}$ CFS solution prepared in 2 replicates. Each of the enzyme; proteinase K (Thermo Fisher Scientific, USA), trypsin (SAFC Biosciences, USA), bromelain (Sigma Aldrich, USA), catalase (Sigma Aldrich, USA) and lysozyme (Thermo Fisher Scientific, USA), at $1.0 \mathrm{mg} / \mathrm{ml}$ was diluted into respective buffer and $\mathrm{pH}$. Each enzyme dilution was added with CFS solution in a ratio of 1:1 v/v. Each reaction was $\mathrm{pH}$ adjusted with either $\mathrm{HCl}$ or $\mathrm{NaOH}$ to suit the optimum $\mathrm{pH}$ recommended by manufacturer; proteinase $\mathrm{K}(8.0)$, trypsin (7.8), bromelain (4.5), catalase (6.0) and lysozyme (4.5); and all mixtures were incubated at $37^{\circ} \mathrm{C}$ for 24 hour and reactions were terminated by heating at $100^{\circ} \mathrm{C}$ for $3 \mathrm{~min}$. A control was prepared for each enzyme treatment but without the addition of the enzyme. Next, all reacted mixtures were tested using agar well diffusion method against $V$. parahaemolyticus to determine the residual activities. Tests were also carried out using two surfactants (triton X-100 and tween 80). Each surfactant was added at $1 \% \mathrm{v} / \mathrm{v}$ into $200 \mu \mathrm{L} \mathrm{CFS}$, followed by incubation at $30^{\circ} \mathrm{C}$ for $1 \mathrm{~h}$. For exposure to UV radiation, CFS were exposed at $0.6 \mathrm{~m}$ under UV light source and inhibitions were similarly measured. The inhibitory activities for all type of treatments were measured in residual activities calculated using the following equation:

$$
\text { Residual activity }(\%)=\frac{I(\mathrm{~mm})-9.0(\mathrm{~mm})}{I o(\mathrm{~mm})-9.0(\mathrm{~mm})} \times 100
$$

Whereby, I represents the inhibition size observed for the test or treated samples; $I_{o}$ represents inhibition for untreated or control samples. The actual size of the well was measured and taken as $9.0 \pm 0.1 \mathrm{~mm}$.

\section{Inhibitory and growth studies}

About $500 \mathrm{ml}$ of MRS broth was seeded with $5.0 \mathrm{ml}$ overnight culture of LAB strain and incubated at $30^{\circ} \mathrm{C}$ for 30 hours. The $\mathrm{pH}, \mathrm{OD}$ at $600 \mathrm{~nm}$ were measured and the viable cell numbers were calculated by plating $20.0 \mu \mathrm{L}$ of growth mixture on MRS agar plate, at 2 hours interval. To get the viable cell number, the visible colonies were counted in $\mathrm{CFUml}^{-1}$ and converted to logarithmic value (log $\left.\mathrm{CFUml}^{-1}\right)$. At each interval, $1.0 \mathrm{ml}$ sample was filter-sterilized $(0.22 \mu \mathrm{m}$, Millipore), and $100 \mu \mathrm{L}$ of filtrate was used in agar well diffusion method for inhibition test against $V$. parahaemolyticus.

\section{Mode of inhibition studies}

The effect of CFS of the isolates containing bacteriocin on the pathogenic $V$. parahaemolyticus growth was evaluated according to Ajitha et al. (2004) Cultivated $V$. parahaemolyticus in $5.0 \mathrm{~mL}$ of NB at cell density of approximately $2 \times 10^{6} \mathrm{CFUml}^{-1}$ was individually supplemented with $2.0 \mathrm{~mL}$ of CFS from LAB The CFS containing putative bacteriocin with inhibitory strength at $164 \mathrm{AUml}^{-1}$, and another one adjusted at $84 \mathrm{AUml}^{-1}$ by dilution. The control $\left(0 \mathrm{AUml}^{-1}\right)$ contained only filter-sterilised NB broth. All tubes in 3 replicates were then incubated at $30{ }^{\circ} \mathrm{C}$ for $48 \mathrm{hrs}$. The growth at 2 hours interval was recorded by measuring the $\mathrm{OD}$ at $600 \mathrm{~nm}$, and the viable cell (in CFU/ml) was estimated by spreading $20.0 \mu \mathrm{L}$ of broth mixture onto NA agar followed by incubation at $30^{\circ} \mathrm{C}$ for $48 \mathrm{hrs}$. In all parts of the work, antimicrobial activities in CFS were defined in $\mathrm{AUml}^{-1}$ which was estimated by estimating the reciprocal of the highest of two fold dilution producing a clear zone of inhibition. 


\section{RESULTS}

\section{Screening and antagonism tests}

Eighty potential LAB strains were isolated from intestines of the Black tip shark Carcharhinus limbatus. In spot on lawn assay (Figure 1b), out of these 80 isolates, only 4 (strain FA1, FA2, FA3 and FA4) demonstrated antimicrobial effect on indicator strains tested; Staphylococcus aureus, Bacillus cereus, Escherichia coli, Pseudomonas aeruginosa, Salmonella typhimurium, Vibrio alginolyticus and Vibrio parahaemolyticus. The cell free supernatant (CFS) from all strains were tested against the same indictor strains and the inhibition results were measured and shown on the Table 1 . All strains recorded a varying level of inhibitions depending on indicator strain used. On agar well difussion assay, slight inhibition (less than $5.0 \mathrm{~mm}$ ) were observed on $P$. aeroginosa. Moderate inhibitions in the range of 10.0 to $18.0 \mathrm{~mm}$ were observed on several indicator strains such as Staphylococcus aureus, Bacillus cereus, Escherichia coli, Salmonella typhimurium and Vibrio alginolyticus. Large inhibition $(\sim 19.0 \mathrm{~mm})$ was measured against Vibrio parahaemolyticus (see Figure 1c as an example). Morphological observations indicated that the strains appeared as purple gram positive stain with coccoid morphologies, non-spore former and lack of motility (Figure 1a). Biochemical tests showed that these strains were catalase and oxidase negative and all were able to ferment lactose (see Table 2). Due to large inhibition demonstrated against indicator strain $V$. parahaemolyticus, LAB isolate FA2 was then selected for subsequent time course growth inhibition and mode of inhibition studies. a)

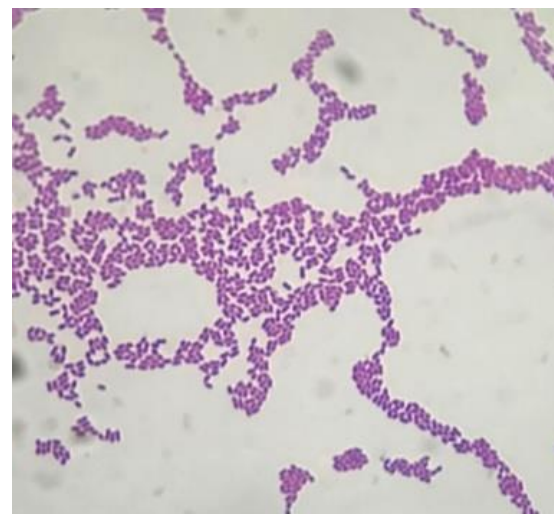

b)

c)

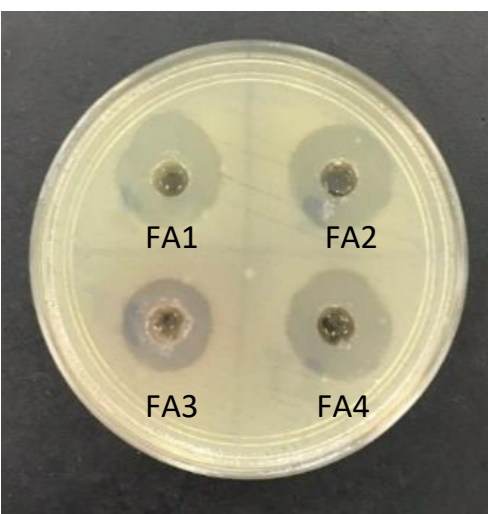

Figure 1a-c. (a) Light microscopy of a selected LAB strain (strain FA2) showing gram positive purple stain with coccus morphology (Magnification 1000x using oil immersion, Nikon). (b) Example of preliminary screening using spot on lawn assay on NA plates with indicator strain Straphylococcus aureus. c). An example of zones of inhibitions observed using agar well diffusion methods with Lactic acid bacteria strains against $V$. parahaemolyticus on NA plates.

Table 1 Antagonistic studies of cell free supernatant (CFS) from LAB strain FA1, FA2, FA3 and FA4 using agar well diffusion method on several indicator strains.

\begin{tabular}{lccc}
\hline \multicolumn{1}{c}{ Indicator strains } & \multicolumn{2}{c}{ Lactococcus lactis strains } \\
\cline { 2 - 4 } & FA1 & FA2 & FA3 \\
\hline Staphylococcus aureus & +++ & +++ & ++ \\
Bacillus cereus & ++ & ++ & ++ \\
Escherichia coli & ++ & ++ & ++ \\
Pseudomonas aeruginosa & + & ++ & + \\
Salmonella typhimurium & ++ & ++ & ++ \\
Vibrio parahaemolyticus & ++++ & +++ & ++ \\
Vibrio alginolyticus & ++ & ++ & +++ \\
\hline The + sign represents distance $d$ of antimicrobial activity with inhibition size in mm. Positive signs; $(++++)$ indicates inhibition size of at least 18.0 mm; $(+++)$
\end{tabular}

The + sign represents distance $d$ of antimicrobial activity with inhibition size in $\mathrm{mm}$. Positive signs; $(++++)$, indicates inhibition size
indicates inhibition of $10.0<d<18.0 \mathrm{~mm} ;(++)$ indicates inhibition of $5.0<d<10.0 \mathrm{~mm}$ and; $(+)$ indicates inhibition of $\mathrm{d} \leq 5.0 \mathrm{~mm}$

Table 2 Biochemical and morphological studies on four LAB strain isolated from sharks.

\begin{tabular}{|c|c|c|c|c|c|c|}
\hline Isolate & Gram stain & Shape & Catalase test & Oxidase test & $\begin{array}{c}\text { Lactose } \\
\text { fermentation }\end{array}$ & Motility \\
\hline FA1 & positive & Coccoid & - & - & + & None \\
\hline FA2 & positive & Coccoid & - & - & + & None \\
\hline FA3 & positive & Coccoid & - & - & + & None \\
\hline FA4 & positive & Coccoid & - & - & + & None \\
\hline
\end{tabular}

\section{Genotypic characterisation}

Following ribosomal rRNA sequencing, the four generated sequences were deposited into NCBI Genebank and each was assigned with a new accession number; MN975529 for strain FA1, MN982712 for strain FA2, MN982711 for strain FA3 and MN982710 for strain FA4. The similarity search carried out using NCBI Genebank database produced hit lists of which were predominantly from Lactococcus spp., with an at least $92 \%$ identity (Table 3). Several strains were selected, aligned and used to construct a phylogenetic tree as shown in Figure 2 Phylogenetic tree constructed has spanned almost all representative species from Lactococcus genera. In the tree, several selected genera from Phylum Firmicutes, i.e. Lactobacillus, Streptococcus, Enterococccus and Streptococcus are included and they form an outgroup cluster outside Lactococcus. Streptococcus pyogenes represents the most distant outgroup. Meanwhile, LAB strain FA1, FA2, FA3 and FA4 are all clustered in a clade consisting of closely related (at least $99 \%$ ) member of Lactococcus lactis, with defined subspecies level; namely the subsp. cremories, tructia, lactis and hordniae. 
Table 3 An example of a list of hits generated from BLASTN tool homology search for 16s RNA sequence. Strains from Lactococcus genera form at least $92 \%$ identity.

\begin{tabular}{|c|c|c|c|c|c|}
\hline Lactic Acid Bacteria Strains & Accession & $\begin{array}{l}\text { Percentage } \\
\text { identity }\end{array}$ & E-value & $\begin{array}{l}\text { Total } \\
\text { score }\end{array}$ & Max score \\
\hline $\begin{array}{l}\text { Lactococcus lactis subsp. tructae } \\
\text { Lactococcus lactis subsp. }\end{array}$ & NR_116443.1 & 99.8 & 0 & 1178 & 1912 \\
\hline $\begin{array}{l}\text { hordniae } \\
\text { Lactococcus lactis subsp. }\end{array}$ & NR_040956.1 & 99.8 & 0 & 1157 & 1912 \\
\hline cremoris & NR_113925.1 & 99.7 & 0 & 1156 & 1908 \\
\hline Lactococcus lactis subsp. lactis & LC_547224.1 & 99.7 & 0 & 1157 & 1908 \\
\hline Lactococcus taiwanensis & NR_114327.1 & 98.6 & 0 & 1179 & 1854 \\
\hline Lactococcus hircilactis & NR_136465.1 & 94.3 & 0 & 1170 & 1642 \\
\hline Lactococcus nasutitermitis & NR_147780.1 & 94.0 & 0 & 1177 & 1633 \\
\hline Lactococcus fujiensis & NR_112882.1 & 93.4 & 0 & 1175 & 1606 \\
\hline Lactococcus garvieae & NR_113268.1 & 93.3 & 0 & 1179 & 1601 \\
\hline Lactococcus laudensis & NR_136466.1 & 93.2 & 0 & 1172 & 1595 \\
\hline Lactococcus garvieae subsp. & & & & & \\
\hline Bovis & NR_152050.1 & 93.2 & 0 & 1117 & 1585 \\
\hline Lactococcus plantarum & NR_044358.1 & 93.0 & 0 & 1139 & 1580 \\
\hline Lactococcus chungangensis & NR_044357.1 & 93.0 & 0 & 1146 & 1579 \\
\hline Lactococcus raffinolactis & NR_113959.1 & 92.8 & 0 & 1166 & 1572 \\
\hline Lactococcus raffinolactis & NR_044359.1 & 92.8 & 0 & 1134 & 1572 \\
\hline Lactococcus piscium & NR_043739.1 & 92.7 & 0 & 1108 & 1568 \\
\hline Lactococcus formosensis & NR_114366.1 & 92.3 & 0 & 1181 & 1552 \\
\hline Streptococcus saliviloxodontae & NR_126178.1 & 91.7 & 0 & 1158 & 1518 \\
\hline Streptococcus equinus & NR_042052.1 & 91.4 & 0 & 1081 & 1505 \\
\hline Streptococcus lutetiensis & NR_042051.1 & 91.3 & 0 & 1110 & 1500 \\
\hline Streptococcus dysgalactiae & NR_118303.1 & 90.1 & 0 & 1079 & 1442 \\
\hline Streptococcus ictaluri & NR_115802.1 & 90.1 & 0 & 1158 & 1440 \\
\hline
\end{tabular}

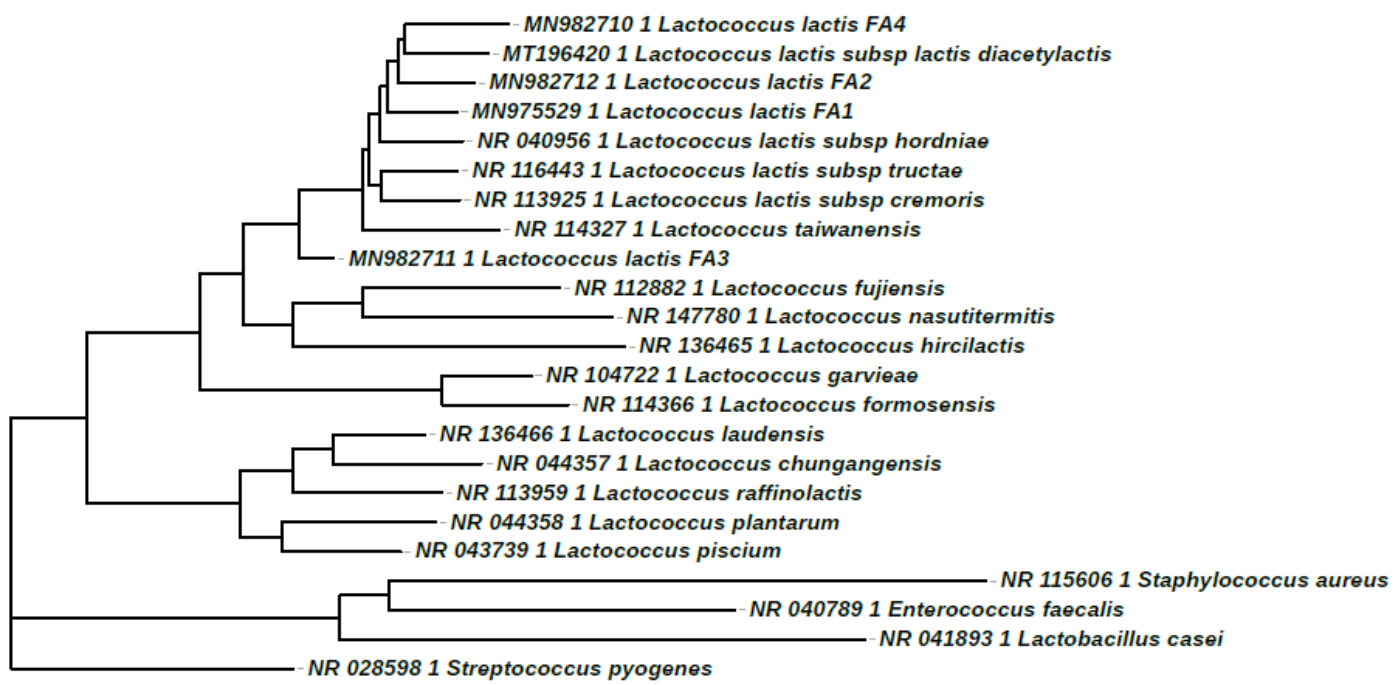

Figure 2 A phylogram generated using selected 16 rRNA gene sequences from representative member of Lactococcus genera. The tree is constructed using improved version of Neighbour Joining (NJ) methods. Each strain is shown with NCBI accession number, together with the LAB strain FA1, FA2, FA3 and FA4 isolated from shark. Other non-Lactococcus Firmicute member (e.g., Enterococcus, Streptococcus, Lactobacillus and Staphylococcus) is respectively represented by a strain, and all of them form an outgroup clade.

\section{Characterization of bacteriocin component in CFS}

Several studies on the physical and biochemical characterisations of bacteriocin component in the CFS were carried out. As shown in Table 4, results showed that inhibitory activities were almost retained following various treatments such as proteolytic enzymes, temperatures, surfactant and UV radiation. Trypsin was able to totally inactivate the inhibitory activities of the CFS, while other enzymes resulted in varying degree of retain of inhibition. Figure 3 shows the residual activities of the CFS against several $\mathrm{pH}$ treatments. Generally, as $\mathrm{pH}$ was increased there was a notable drop in residual activities at $\mathrm{pH} 6.0$ onwards and there was a total inactivation at $\mathrm{pH} 10$.
Table 4 The results of enzymes, temperature and other treatments on cell free supernatant (CFS) from strain FA2.

\begin{tabular}{llcc}
\hline Treatments & & $\begin{array}{c}\text { Inhibition } \\
\text { zone } \mathbf{( m m} \\
\mathbf{\pm 0 . 1} \mathbf{m m})\end{array}$ & $\begin{array}{c}\text { Residual } \\
\text { activities } \\
(\mathbf{\%})\end{array}$ \\
\hline Protease & Control & 19.6 & 100 \\
& Trypsin & 0.0 & 0.0 \\
& Proteinase $\mathrm{K}$ & 4.10 & 20.9 \\
& Bromelain & 16.2 & 82.6 \\
& Catalase & 19.2 & 97.9 \\
& Lysozyme & 9.8 & 50.0 \\
Temperatures $(\mathbf{1 0} \mathbf{~}$ min) $)$ & Control & 19.4 & 100.0 \\
& $50^{\circ} \mathrm{C}$ & 19.2 & 97.8 \\
& $80^{\circ} \mathrm{C}$ & 18.9 & 95.0 \\
& $100^{\circ} \mathrm{C}$ & 18.7 & 92.8 \\
& Control & 20.0 & 100.0 \\
& Tween 80 & 20.0 & 100.0 \\
& Triton $\mathrm{X}-100$ & 20.0 & 100.0 \\
& $\mathrm{UV}$ & 20.0 & 100.0 \\
\hline
\end{tabular}




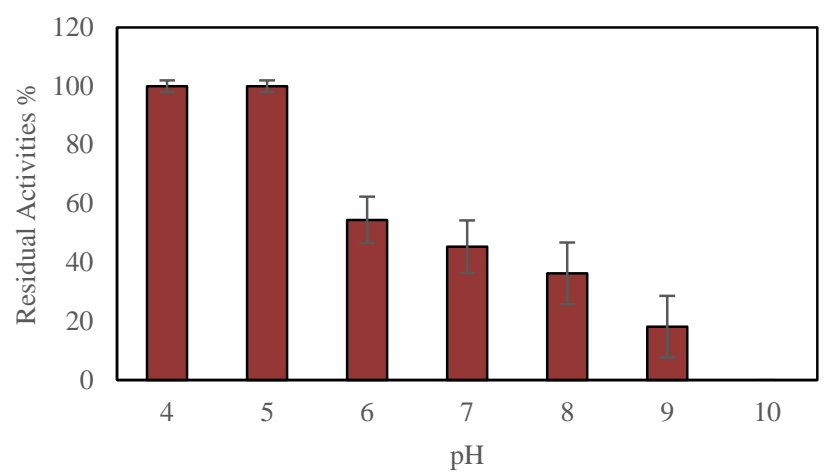

Figure 3 Effect of $\mathrm{pH}$ on the inhibitory activities of CFS from LAB strains. As $\mathrm{pH}$ was increased, inhibitory activities gradually dropped at $\mathrm{pH} 6.0$ and above

\section{Inhibitory activities and growth studies}

Results in Figure 4 showed the effect of CFS taken from different growth phase of LAB (strain FA2) within 30 hours of incubation at $30^{\circ} \mathrm{C}$ on the degree of inhibition against indicator organism $V$. parahaemolyticus.

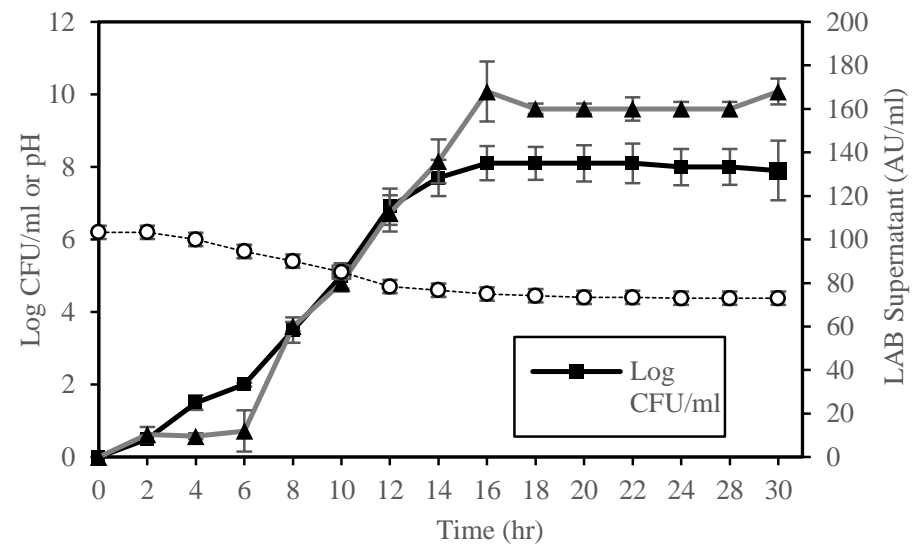

Figure 4 Growth of LABs strain FA2, the inhibitory activities and $\mathrm{pH}$ changes during the 30 hours incubation in $500 \mathrm{ml}$ batch culture using MRS broth.

\section{Mode of inhibition studies}

As shown in Figure 5, the administration of different levels of CFS dilution (0 $\mathrm{AUml}^{-1}, 84.0 \mathrm{AUml}^{-1}$ and $168.0 \mathrm{AUml}^{-1}$ ) on the growth of indicator organism $V$. parahaemolyticus, with 30 hours period incubation at $30^{\circ} \mathrm{C}$. Compared to untreated control $\left(0 \mathrm{AUml}^{-1}\right)$, viable cell numbers in $\log \mathrm{CFUml}^{-1}$ were depleted in a dose dependent manner. The cell number depletions signified that CFS component exerted bactericidal effect upon inhibiting the target bacteria.

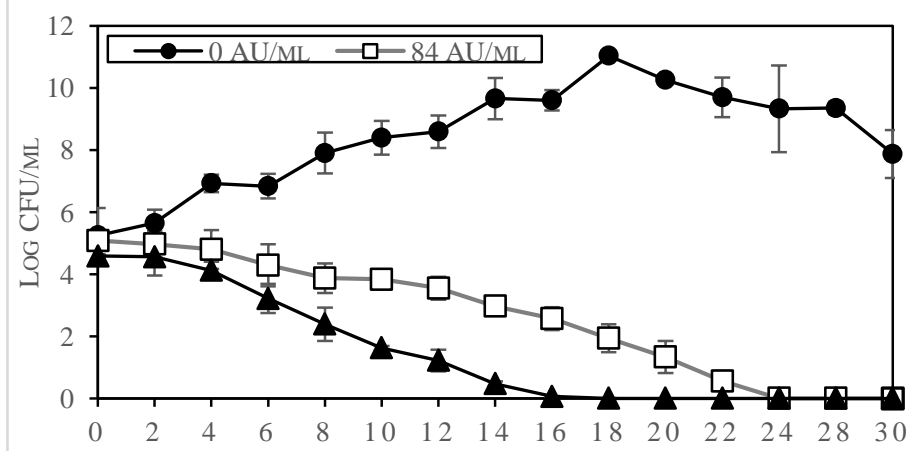

TIME (HR)

Figure 5 The effect of CFS from LAB strain FA2 containing bacteriocin on the growth of indicator strain $V$. parahaemolyticus. Three experiments were carried out using different levels of CFS dilutions at $(0,84$ and $168 \mathrm{AU} / \mathrm{ml})$.

\section{DISCUSSION}

The sequencing results showed that rRNA sequences for 4 isolates are at least $99.7 \%$ similar to those of Lactococcus lactis. This level of percentage similarity is well above the cut-off point or threshold limit accepted for genus (95\%) and species (98.7\%) (Rossi-Tamisier et al., 2015). Phylogenetic tree constructed clustered all LAB isolates into a clade consisting of several L. lactis subspecies. Meanwhile, the results from morphological and biochemical tests were consistent with the ribosomal RNA sequencing, thus confirmed that the 4 strains belonging to genus Lactococcus which is gram positive coccus, lactose fermenter, nonsporformer and non-motile. Thus far, this could represent the only report on the isolation of L. lactis from shark. Unlike in human or land animal, L. lactis was known to present in a small population and uncommon in fish microbiota. Nevertheless, the presence of LAB is believed to contribute to overall microbial balance in the shark gut. Ability to retain their small population could be due to their unique properties. For instance, the release of bacteriocin helps the LAB strains survive and compete with other dominating microbes in the shark intestine. These strains were unique in showing broad spectrum inhibition to both gram positive and gram negative bacterium. The presence of bacteriocin such as nisin is common among L. lactis strain. Nisin usually displayed strong inhibition against gram positive bacterium but in gram negative bacterium, it was protected by the lipopolysaccharide (LPS) layer (Zhou et al., 2016). Ability of this strain to inhibit gram negative bacterium worth a further investigation. Meanwhile, antagonisms were observed against gram negative pathogens commonly encountered in aquaculture. These include $V$. parahaemolyticus, highly implicated in a shrimp disease called Early Mortality Syndrome (EMS) (Kua et al., 2016); and $V$. alginotlyticus, the most pathogenic species found in many marine aquatic animals (Cao et al., 2018). These LAB strains therefore have huge potential for probiotic candidates in shrimp or fish aquacultures. Moreover, fish derived probiotics has many proven benefits in aquaculture. The so called 'host associated probiotics' were shown to be more superior to probiotic derived from non-aquaculture or other animal sources (Van Doan et al., 2020).

Inhibitory activities of the CFS were almost retained following treatment in 10 minutes at $50^{\circ} \mathrm{C}, 80^{\circ} \mathrm{C}$ and $100^{\circ} \mathrm{C}$ incubations. Studies on nisin from L. Lactis reported that it was thermostable at lower $\mathrm{pH}$ range, but not at higher $\mathrm{pH}$ range (Gharsallaoui et al., 2015). Since we have assayed at $\mathrm{pH} 6.0$, no inactivation was expected and all the residual activities were at least $92 \%$ at these temperatures. Treatment of CFS at different $\mathrm{pH}$ showed that as $\mathrm{pH}$ was increased, the residual inhibitory activities of the CFS was reduced noticeably from $\mathrm{pH} 6$ and above. Pasteris et al. (2013) also reported that the optimized activities against Listeria monocytogenes of bacteriocin from L. lactis was found to be at $\mathrm{pH}$ 5.0-6.5. This observation is so typical for nisin and this was generally thought due to the loss in solubility of nisin which occurs at pH 6 and above (IbarraSánchez et al., 2020). Effect of $\mathrm{pH}$ was rather complex since an increased in inhibitory activities at a lower $\mathrm{pH}(<\mathrm{pH} 5)$ could also be due to acidity. Treatment with several proteolytic enzymes were also carried out. The inhibition activities were almost completely lost following treatment with trypsin, an indication on the proteinaceous properties of inhibitory molecule in the CFS About $79.1 \%$ lost in residual activities was observed following treatment with proteinase K. Meanwhile, about $17.4 \%$ activity was lost upon treatment with bromelain. Different proteolytic enzymes are known to cleave peptide at different recognition sequences in peptide, thereby could result in different efficiencies in degradation. Lysozyme treatment resulted in 50\% lost in activities showing the inhibitory activities could also be contributed by other non-protein componen like polysaccharides which is sensitive to lysozyme. Hydrogen peroxide is an antimicrobial compound produced by some microorganisms. Since treatment with catalase had no effect on inhibition, hydrogen peroxide which is the substrate for catalase was not involved in causing the inhibition. The inhibition was also unaffected by surfactants and UV light which were common observations. L. lactis is widely known to produce nisin and for these strains, substantial evidences indicated that component in CFS resembled to that of nisin (Matsusaki et al., 1998).

CFS from different growth phases of LAB (strain FA2) showed different degree of inhibition on indicator organism Vibrio parahaemolyticus. There was no inhibition within the first 6 hour of the lag phase. The inhibition were noticeable at the onset of logarithmic growth phase, in which the inhibition has increased from $0.8 \mathrm{AU} / \mathrm{ml} \mathrm{(at} \mathrm{t}=6 \mathrm{hr}$ ) to up to $168 \mathrm{AU} / \mathrm{ml}$ (at $\mathrm{t}=16 \mathrm{hr}$ ). The level of inhibition reached maximum at 9.5 to $10.0 \mathrm{AU} / \mathrm{ml}$ during the early part of stationary phase (16 hours). The $\mathrm{pH}$ values dropped throughout the growth from 6.2 (at $\mathrm{t}=0 \mathrm{hr}$ ) down to 3.8 during stationary phase, a hallmark of lactose being fermented into lactic acid. This observation was consistent with a similar work by Pasteris et al. (2013) on L. lactis strain against indicator L. monocytogenes. This type of growth-associated inhibition profile were common in many other studies on bacteriocin (Barman et al., 2018; Goh et al., 2015; Kormin et al., 2001). This agrees well with the fact that nisin, a primary metabolite, is produced through ribosomal transcription; as in contrast to antibiotic, a secondary metabolite which is otherwise produced during the stationary phase (Abee $\boldsymbol{e t}$ al., 2003).

The administration of different levels of CFS dilution (at time $t=0 \mathrm{hr}$ ) have different effects on the growth of indicator organism $V$. parahaemolyticus. In a 
concentration dependent manner, the level of CFS added resulted in depletion of viable cell number compared to the control without the addition of CFS. The viable cell numbers reached 0 at time 16 hours for CFS (at $168 \mathrm{AU} / \mathrm{ml}$ ); and at 24 hours for CFS (at $84 \mathrm{AU} / \mathrm{ml}$ ), respectively. The depletion in viable cell number in the course of incubation period indicated that CFS containing nisin-like compound has caused bactericidal effect as a result of cellular lysis (Matsusaki et al., 1998; Thirumurugan et al., 2019). Nisin usually attacks by forming pore on target cell triggering subsequent cellular lysis. This is however opposed to viable cell number remaining at a static value, a hallmark in bacteriostatic effect (Mulyani et al., 2019).

\section{CONCLUSION}

Four LAB strains from Lactococcus lactis were successfully isolated from the intestine of Black tip shark captured from Malaysian East Coast waterways. This is one of a very few report on the isolation of LAB belonging to this strain from shark. These strains display broad spectrum inhibition and able to antagonise both gram positive and gram negative bacterium being tested. Meanwhile, these strains are found to be bacteriocinogenic, able to produce nisin-like compound, a type of bacteriocin frequently found to be produced by L. lactis strains. Ability to produce bacteriocin is considered a desirable properties of probiotics. Since these strains show good antagonisms towards Vibrio spp., which are common pathogens in aquaculture, they have bright prospect to be the future probiotic for aquaculture industries and management.

Acknowledgments: The authors wish to thank to the Ministry of Higher Education, Malaysia; and the International Islamic University Malaysia (IIUM) for completing this work under grant no RIGS17-089-0664 IIUM KPT.

\section{REFERENCES}

Abee, T. , \& Delves-Broughton, J. (2003). Bacteriocins - Nisin. In N. J. Russell \& G. W. Gould (Eds.), Food Preservatives (pp. 146-147). Boston, USA Springer.

Ahmad, A. , Hamid, R. , Dada, A.C., \& Usup, G. (2013). Pseudomonas putida strain FStm2 isolated from shark skin: A potential source of bacteriocin. Probiotics and Antimicrobial Proteins, 5(3), 165-175 https://doi.org/10.1007/s12602-013-9140-4

Ajitha, S. , Sridhar, M., Sridhar, N. , Singh, I.S.B. , \& Varghese, V. (2004) Probiotic effects of Lactic acid bacteria against Vibrio alginolyticus in Penaeus (Fenneropenaeus) indicus (H. Milne Edwards). Asian Fisheries Science, 17, 7180

Amenyogbe, E., Chen, G., Wang, Z., Huang, J., Huang, B. , \& Li, H. (2020). The exploitation of probiotics, prebiotics and synbiotics in aquaculture: present study, limitations and future directions: A review. Aquaculture International, 28, 1017 1041. https://doi.org/10.1007/s10499-020-00509-0

Banerjee, S. K. (2013). Antibacterial activity of Neem (Azadirachta indica) leaves on Vibrio spp. isolated from cultured shrimp. Asian Journal of Animal and Verterinary Advances, 8(2), 355-361. https://doi.org/10.3923/ajava.2013.355.361 Barman, S. , Ghosh, R. , \& Mandal, N.C. (2018). Production optimization of broad spectrum bacteriocin of three strains of Lactococcus lactis isolated from homemade buttermilk. Annals of Agrarian Science, 16(3), 3286-3296. https://doi.org/10.1016/j.aasci.2018.05.004

Bindiya, E.S. , Tina, K.J. , Raghul, S.S. , \& Bhat, S.G. (2015). Characterization of Deep Sea fish gut bacteria with antagonistic potential, from Deep Sea shark. Probiotics and Antimicrobial Proteins, 7(2), 157-163. https://doi.org/10.1007/s12602-015-9190-x

Cao, J., Zhang, J., Ma, L. , Li, L., Zhang, W. , \& Li, J. (2018). Identification of fish source Vibrio alginolyticus and evaluation of its bacterial ghosts vaccine immune effects. MicrobiologyOpen, 7(3). Retrieved from Wiley Online Library website: https://doi.org/10.1002/mbo3.576 https://www.ncbi.nlm.nih.gov/pubmed/29349911

Edwards, U., Rogall, T. , Blocker, H. , Emde, M. , \& Bottger, E.C. (1989) Isolation and direct complete nucleotide determination of entire genes. Nucleic Acid Research 17, 7843-7853. https://doi.org/10.1093/nar/17.19.7843

Gharsallaoui, A. , Oulahal, N. , Joly, C. , \& Degraeve, P. (2015). Nisin as a food preservative: Part 1: Physicochemical properties, antimicrobial activity, and main uses. Critical Reviews in Food Science and Nutrition, 56(8), 1262-1274. https://doi.org/10.1080/10408398.2013.763765

Gibson, G., Hutkins, R., Sanders, M. , Sanders M. E., Prescott, S. L., Reimer, R. A., Salminen S. J., Scott, K., Stanton, C., Swanson, K. S., Cani, P. D., Verbeke, K., \& Reid, G. (2017). Expert consensus document: The International Scientific Association for Probiotics and Prebiotics (ISAPP) consensus statement on the definition and scope of prebiotics. Nature Reviews Gastroenterology and Hepatology, 14, 491-502. https://doi.org/10.1038/nrgastro.2017.75

Givens, C.E., Ransom, B. , Bano, N. , \& Hollibough, J. T. (2015). Comparison of the gut microbiomes of 12 bony fish and 3 shark species. Marine Ecology Progress Series, 518, 209-223. https://doi.org/10.3354/meps11034
Goh, H.F. , \& Philip, K. (2015). Purification and characterization of bacteriocin produced by Weissella confusa A3 of dairy origin. PLOS ONE, 10(10). https://doi.org/10.1371/journal.pone.0140434

Hata, T., Tanaka, R., \& Ohmomo, S. (2010). Isolation and characterization of plantaricin ASM1: A new bacteriocin produced by Lactobacillus plantarum A-1. International Journal of Food Microbiology, 137(1), 94-99. https://doi.org/10.1016/i.ijfoodmicro.2009.10.021

Heller, K. J. (2001). Probiotic bacteria in fermented foods: product characteristics and starter organisms. The American Journal of Clinical Nutrition, 73(2), 374s 379s. https://doi.org/10.1093/ajen/73.2.374s

Ibarra-Sánchez, L.A., El-Haddad, N. , Mahmoud, D. , Miller, M.J. , \& Karam, L. (2020). Invited review: Advances in nisin use for preservation of dairy products Journal of Dairy Science., 103(3), 2041-2052. https://doi.org/10.3168/jds.2019 $\underline{17498}$

Jiang, H., Zou, J., Cheng, H., J., Fang, \& Huang, G. (2017). Purification, characterization, and mode of action of pentocin JL-1, a novel bacteriocin isolated from Lactobacillus pentosus, against drug-resistant Staphylococcus aureus. BioMed Research International, 2017, 1-11. https://doi.org/10.1155/2017/7657190

Kormin, S., Rusul, G. , Radu, S. , \& Ling, F.H. (2001). Bacteriocin-producing lactic acid bacteria isolated from traditional fermented food. Malaysian Journal of Medical Sciences, 8, 63-68

Kua, B.C., Ahmad, I.A.R., Siti Zahrah, A., Irene, J. , Norazila, J. , Nik Haiha N.Y. , Fadzilah, Y., Mohammed, M. , Siti Rokhaiya, B., Omar, M. , \& Teoh, T.P. (2016, 22-24 February 2016). Current status of acute hepatopancreatic necrosis disease (AHPND) of farmed shrimp in Malaysia. Paper presented at the Addressing Acute Hepatopancreatic Necrosis Disease (AHPND) and other transboundary diseases for improved aquatic animal health in Southeast Asia: Proceedings of the ASEAN Regional Technical Consultation on EMS/AHPND and other transboundary diseases for improved aquatic animal health in Southeast Asia, Makati City, Philippines

Lazado, C.C., Caipang, C.M.A. , \& Estante, E.G. (2015). Prospects of hostassociated microorganisms in fish and penaeids as probiotics with immunomodulatory functions. Fish and Shellfish Immunology, 45(1), 2-12. https://doi.org/10.1016/j.fsi.2015.02.023

Lemoine, F. , Correia, D. , Lefort, V. , Doppelt-Azeroual, O. , Mareuil, F. Cohen-Boulakia, S., \& Gascuel, O. (2019). NGPhylogeny.fr: new generation phylogenetic services for non-specialists. Nucleic Acids Research, 47(W1), W260-W265. https://doi.org/10.1093/nar/gkz303

Lima, E.T. , Andreatti Filho, R. L., Okamoto, A.S. , Noujaim, J.C., Barros, M.R. , \& Crocci, A.J. (2007). Evaluation in vitro of the antagonistic substances produced by Lactobacillus spp. isolated from chickens. Canadian Journal of Veterinary Research, 71(2), 103-107

Matsusaki, H., Sonomoto, K. , \& Ishizaki, A. (1998). Some characteristic of Nisin Z, a peptide antibiotic produced by Lactococcus lactis IO-1. Food Science and Technology Internatinal Tokyo, 4(4), 290-294. https://doi.org/10.3136/fsti9596t9798.4.290

Mulyani, S. , Jenie, B.S.L., Kusumaningrum, H.D., \& Arief, I.I. (2019) Characterisation of crude bacteriocin produced by Pediococcus pentosaceus $2 \mathrm{~A} 2$ in enriched molasses medium. International Food Research Journal, 26(1), 187 192

Ninawe, A. S. , \& Selvin, J. (2009). Probiotics in shrimp aquaculture: Avenues and challenges. Critical Reviews in Microbiology, 35(1), 43-66. https://doi.org/10.1080/10408410802667202

Oelschlaeger, T. A. (2010). Mechanisms of probiotic actions - A review. International Journal of Medical Microbiology, 300(1), 57-62. https://doi.org/10.1016/j.ijmm.2009.08.005

Pasteris, S.E. , Vera Pingitore, E., Ale, C.E. , \& Nader-Macías, M.E.F. (2013) Characterization of a bacteriocin produced by Lactococcus lactis subsp. lactis CRL 1584 isolated from a Lithobates catesbeianus hatchery. World Journal of Microbiology and Biotechnology, 30(3), 1053-1062. https://doi.org/10.1007/s11274-013-1524-9

Qiagen. (2016). QIAamp DNA Mini and Blood Mini handbook (pp. 55-58).

Rossi-Tamisier, M., Benamar, S., Raoult, D. , \& Fournier, P-E. (2015) Cautionary tale of using $16 \mathrm{~S}$ rRNA gene sequence similarity values in identification of human-associated bacterial species. International Journal of Systematic and Evolutionary Microbiology, 65(Pt 6), 1929-1934. https://doi.org/10.1099/ijs.0.000161

Thirumurugan, A., Sheela, R. , \& Singh, A.K. (2019). Growth profile and partial characterization of bacteriocin produced by Lactobacillus plantarum ATM11 isolated from slaughterhouse soil. Songklanakarin Journal of Science and Technology, 41(1), 37-44. https://doi.org/10.14456/sjst-psu.2019.5

Van Doan, H., Hoseinifar, S.H., Ringø, E., Esteban, M.Á., Dadar, M. , Dawood, M.A.O. , \& Faggio, C. (2020). Host-associated probiotics: A key factor in sustainable aquaculture. Reviews in Fisheries Science and Aquaculture, 28(1), 16-42. https://doi.org/10.1080/23308249.2019.1643288

Yusuf, M.A. , \& Hamid, T.H.T.A. (2013). Isolation of coagulase negative Enterococcous sp. strains from non-broiler chicken producing bacteriocin active against Staphylococcus aureus. Journal Agrobiology, 30(1), 33-42. https://doi.org/10.2478/agro-2013-0004 
Zhen-Xing, X., Qi-Yun, L., De-Chen, L., Guan-Jun, C. , \& Zong-Jun, D. (2016). Pistricoccus aurantiacus gen. nov., sp. nov., a moderately halophilic bacterium isolated from a shark. Antonie van Leeuwenhoek, 109(12), 1593-1603. https://doi.org/10.1007/s10482-016-0760-Z

Zhou, L., Van Heel, A. J., Montalban-Lopez, M. , \& Kuipers, O.P. (2016)

Potentiating the Activity of Nisin against Escherichia coli. Frontiers in Cell and Developmental Biology, 4(7). https://doi.org/10.3389/fcell.2016.00007

Zouhir, A., Hammami, R., Fliss, I. , \& Hamida, J. B. (2010). A new structurebased classification of gram-positive bacteriocins. Protein Journal, 29, 432-439. https://doi.org/10.1007/s10930-010-9270-4 